\title{
ODMOWA PEŁNIENIA SŁUŻBY WOJSKOWEJ PRZEZ ŚWIADKÓW JEHOWY JAKO REALIZACJA KLAUZULI SUMIENIA. UWARUNKOWANIA PRAWNO-HISTORYCZNE
}

\section{UWAGI WSTĘPNE}

Powszechnie znany jest negatywny stosunek Świadków Jehowy do służby z bronią w ręku i wiązanie się z jakąkolwiek formacją militarną. Sam związek wyznaniowy stale podkreśla swoją neutralność i apolityczność. Celem niniejszego artykułu jest przedstawienie stosunku Świadków Jehowy do służby wojskowej oraz reakcja władz na to zjawisko, zarówno w okresie Polski Ludowej, jak i po 1989 roku.

Wpływ na powojenne losy Świadków Jehowy miał fakt, że w $1931 \mathrm{r}$. zostali zarejestrowani jako stowarzyszenie, a nie jako związek wyznaniowy ${ }^{1}$. Spowodowało to, że ich działalność została poddana pod dyspozycję dekretu z dnia 5 sierpnia 1949 r. o zmianie niektórych przepisów prawa o stowarzyszeniach², a dnia 2 lipca 1950 r. Urząd do Spraw Wyznań (UdSW) mógł wydać decyzję uznającą, że wyzna-

${ }^{*}$ Dr hab., Instytut Prawa i Ekonomii, Wydział Zamiejscowy Prawa i Nauk o Społeczeństwie w Stalowej Woli, Katolicki Uniwersytet Lubelski Jana Pawła II, ul. Ofiar Katynia 6a, 37-45- Stalowa Wola, e-mail: bieleckim@wp.pl

${ }^{1}$ Stanisław Ufniarski, Międzynarodowe Stowarzyszenie Badaczy Pisma św. (Świadkowie Jehowy), (Kraków: Wydawnictwo Mariackie, 1947), 54.

${ }^{2}$ Dz.U. Nr 45, poz. 335. 
nie Świadków Jehowy zostało rozwiązane ${ }^{3}$. Od tego momentu liczne przejawy działalności związku karane były więzieniem.

Możliwość ponownej legalizacji działalności pojawiła się w momencie wejścia w życie ustawy z dnia 17 maja 1989 r. o gwarancjach wolności sumienia i wyznania ${ }^{4}$, na podstawie której w dniu 31 stycznia 1990 r. zostali wpisani do rejestru kościołów i innych związków wyznaniowych pod nazwą „Strażnica - Towarzystwo Biblijne i Traktatowe, Zarejestrowany Zwiazek Wyznania Świadków Jehowy w Polsce"s. W 2014 r. zmieniono oficjalną nazwę i zgodnie z decyzją Ministra Administracji i Cyfryzacji z 13 maja 2014 r., zatwierdzono nowy statut, zgodnie z którym w myśl art. 1 związek nosi nazwę "Świadkowie Jehowy w Polsce"6.

Mówiąc o odmowie służby wojskowej, mamy na myśli istnienie tzw. klauzuli sumienia, w ostatnim czasie utożsamianej głównie z zawodem lekarza w odniesieniu do odmowy wykonania zabiegu aborcji. Jednakże należy pamiętać, że obowiązuje ona również w innych sytuacjach życiowych, w tym związanych ze służbą z bronią w ręku. W doktrynie przyjmuje się, że pod pojęciem „klauzula sumienia” bądź „sprzeciw sumienia", należy rozumieć odmowę wykonania obowiązku nałożonego zgodnie z prawem, z powołaniem się na przekonania religijne bądź moralne ${ }^{7}$. Jej źródeł należy dopatrywać się w regulacji zawartej w ustawie zasadniczej, która stanowi, że każda jednostka ludzka ma wolność sumienia i religii ${ }^{8}$. Aktualność zachowuje także orzeczenie Trybunału Konstytucyjnego, który odniósł się do treści art. 82 ust. 1 Konstytucji z 1952 r. (wolność sumienia i wyznania). Zgodnie z wyrażonym wówczas stanowiskiem: „wolność sumienia nie oznacza jedynie

${ }^{3}$ Decyzja UdSW z dnia 2 lipca 1950 r. (L.dz. W II 4/27/67/50).

${ }^{4}$ Dz.U. Nr 29, poz. 155. Ustawa weszła w życie 23 maja 1989 r.

${ }^{5}$ Kościoły i związki wyznaniowe wpisane do rejestru kościołów i związków wyznaniowych - data publikacji 14.01.2013 r., https://mac.gov.pl/files/wp-content/uploads/2011/12/e-rejestr.pdf [dostęp: 26.09.2016].

${ }^{6}$ Załącznik do decyzji Ministra Administracji i Cyfryzacji z dnia 13 maja 2014 r. (DWRMNiE-WROA.6123.1.2014).

${ }^{7}$ Artur Mezglewski, Henryk Misztal, Piotr Stanisz, Prawo wyznaniowe (Warszawa: Wydawnictwo C.H. Beck, 2006), 104.

${ }^{8}$ Konstytucja Rzeczypospolitej Polskiej z dnia 2 kwietnia 1997 r., Dz.U. Nr 78, poz. 483 z późn. zm. 
prawa do reprezentowania określonego światopoglądu, ale przede wszystkim prawo do postępowania zgodnie z własnym sumieniem, do wolności od przymusu postępowania wbrew własnemu sumieniu"9.

Z uwagi na zawieszenie powszechnego obowiązku służby wojskowej, niniejszy artykuł nabiera znaczenia opracowania historycznego, chociaż obserwując ostatnie wydarzenia na arenie międzynarodowej oraz politykę wewnętrzną polskich władz, nie można wykluczyć, że obowiązek ten zostanie ponownie przywrócony.

\section{GENEZA ODMOWY SŁUŻBY Z BRONIĄ W RĘKU}

Kwestia odmowy służby wojskowej ze względu na przekonania religijne pojawiła się już w imperium rzymskim. Zarówno Żydzi, jak i chrześcijanie w pierwszych wiekach po Chrystusie, odmawiali służby $\mathrm{w}$ armii. Ci pierwsi argumentowali to ewentualnością złożenia przysięgi, w której uznawaliby boskość cesarza. Z kolei chrześcijanie opierali się na ewangelicznym nakazie nie zadawania gwałtu ${ }^{10}$. W literaturze przedmiotu możemy spotkać się z opinią, że pierwsi chrześcijanie mogli pozwolić sobie na takie zachowanie z tego względu, iż początkowo nie byli wcielani do armii, bowiem władze obawiały się ich destrukcyjnego wpływu na pozostałych żołnierzy. Sytuacja uległa zmianie, gdy w 380 r. chrześcijaństwo stało się religią państwową. Sformułowana została wówczas idea wojny sprawiedliwej, której twórcą był św. Augustyn. W swoim dziele De Civitate Dei, rozwinął wcześniejsze tezy św. Ambrożego, uznając za sprawiedliwe te wojny, które są prowadzone w celu pomszczenia krzywd lub odzyskania tego, co zostało drogą krzywdy zagarnięte ${ }^{11}$.W epoce

${ }^{9}$ Orzeczenie Trybunału Konstytucyjnego z dnia 15 stycznia 1991 r., U 8/90, OTK ZU 1991, nr 1, poz. 8. Zob. szerzej: Piotr Stanisz, O klauzuli sumienia, http://www.rp.pl/ artykul/1120365 [dostęp: 17.09.2016].

${ }^{10}$ Marcin Mróz, Odmowa służby wojskowej ze względu na przekonania i stużba zastępcza wybranych państw europejskich (Niemcy, Francja, Hiszpania) - raport przygotowany w Biurze Studiów i Ekspertyz Kancelarii Sejmu, Wydział Analiz Ekonomicznych i Społecznych, sierpień 1996 r., http://biurose.sejm.gov.pl/teksty_pdf_96/r-92.pdf [dostęp: 1.07.2016].

${ }^{11}$ Patrycja Grzebyk, ,Idea wojny sprawiedliwej - od starożytności po czasy nowożytne”, Forum Prawnicze 2 (2010): 60. Cytując zdanie św. Augustyna, autorka powołuje się 
nowożytnej postawa odmowy udziału w wojnie pojawia się w XVI w. w radykalnych kościołach protestanckich. W Polsce zakaz ten obowiązywał między innymi u braci polskich. W ostatnich dziesięcioleciach XIX w. zaczęła rozprzestrzeniać się idea armii oparta na powszechnym poborze. W 1922 r. Norwegia, a w 1926 r. Holandia, wprowadzają do swego ustawodawstwa przepisy zezwalające na odbycie zastępczej służby wojskowej, motywowanej względami religijnymi. Po zakończeniu II wojny światowej takie regulacje znajdują uznanie w wielu państwach, nie tylko w tych o tradycjach demokratycznych ${ }^{12}$.

Doktryna Świadków Jehowy przechodziła ewolucję. Podczas pierwszej wojny światowej bez przeszkód mogli oni służyć w armii z bronią w ręku. W listopadzie 1939 r. ogłoszono neutralność organizacji, a zastępcza służba wojskowa (cywilna) zaczęła być brana pod uwagę dopiero od maja 1996 r. ${ }^{13}$ W kwestii noszenie broni, do $1983 \mathrm{r}$. pozwalano Świadkom Jehowy na podejmowanie pracy związanej z jej posiadaniem, po czym wyznaczono sześciomiesięczny termin na zmianę zatrudnienia pod groźbą utraty specjalnych przywilejów służby lub pełnienia odpowiedzialnej funkcji w zborze. Jedyną dopuszczalną formą jej używania są polowania ${ }^{14}$. Do 1988 r., czyli do momentu, kiedy UdSW poinformował wszystkie Wojskowe Komendy Uzupełnień, że doktryna Świadków Jehowy nie zezwala na odbywanie służby wojskowej ani na jakikolwiek związek z organizacjami typu militarnego, sądy za jej odmowę wydawały wyroki skazujące ${ }^{15}$.

na: Św. Augustyn, Problemy Heptateuchu, Część druga, przeł. Jan Sulowski (Warszawa: Akademia Teologii Katolickiej, 1990), 64.

${ }^{12}$ Mróz, Odmowa stużby wojskowej ze względu na przekonania, 2-4.

${ }^{13}$ Włodzimierz Bednarski, Szymon Matusiak, Zmienne nauki Świadków Jehowy. Najważniejsze zmiany $w$ doktrynie Towarzystwa Strażnica $w$ latach 1879-2011 (Warszawa: Wydawnictwo Słowo Prawdy, 2012), 228.

14 Tamże, 243.

${ }^{15}$ Ryszard Michalak, Polityka wyznaniowa państwa polskiego wobec mniejszości religijnych w latach 1945-1989 (Zielona Góra: Oficyna Wydawnicza Uniwersytetu Zielonogórskiego, 2014), 148. 
3. REGULACJE NORMATYWNE DOTYCZĄCE MOŻLIWOŚCI ZWOLNIENIA ZE SŁUŻBY WOJSKOWEJ

\subsection{PRAWODAWSTWO KRAJOWE}

Bezpośrednio po zakończeniu wojny, obok regulacji wydawanych przez władze reprezentujące nowy ustrój, swoją aktualność zachowywały akty normatywne uchwalone w okresie dwudziestolecia międzywojennego.

Organizację i sposób odbywania służby wojskowej regulowała początkowo ustawa z dnia 9 kwietnia 1938 r. o powszechnym obowiąz$\mathrm{ku}$ wojskowym ${ }^{16}$ (u.p.o.w.). Ustawa nie przewidywała możliwości zwolnienia Świadków Jehowy z tego obowiązku bądź zamiany na tzw. służbę zastępczą ze względu na sprzeciw sumienia. Zawarte były w niej co prawda normy, które odnosiły się do duchownych różnych wyznań, ale ze względu na problematyczny status prawny Świadków Jehowy przed wojną (stowarzyszenie, a nie związek wyznaniowy) i ich delegalizacją w 1950 r., nie mogli korzystać oni z możliwości, które dawała ustawa. Zgodnie $z$ art. 50 ust. 1 lit. g. u.p.o.w., duchowni uznanych przez państwo wyznań chrześcijańskich i niechrześcijańskich, bez poddawania przeglądowi, zostali zaliczeni do pomocniczej służby wojskowej na podstawie dokumentów przedstawionych komisji poborowej. Rozporządzenie wykonawcze do u.p.o.w. wymieniało z imienia uznane związki wyznaniowe ${ }^{17}$. Zgodnie z $\$ 211$ bez poddawania przeglądowi lekarskiemu zostają zaliczeni przy poborze do pomocniczej służby wojskowej następujące osoby:

a) duchowni wyznania katolickiego wszystkich obrządków, którzy otrzymali święcenia; zakonnicy tego wyznania, którzy złożyli śluby zakonne; uczniowie seminariów duchownych; nowicjusze zakonów i zgromadzeń tego wyznania;

${ }^{16}$ Dz.U. Nr 25, poz. 220 z późn. zm.

${ }^{17}$ Rozporządzenie ministrów: spraw wojskowych, spraw wewnętrznych i opieki społecznej, wydane w porozumieniu z ministrami: spraw zagranicznych, rolnictwa i reform rolnych oraz komunikacji z dnia 7 lutego 1939 r. w sprawie wykonania ustawy z 9 kwietnia 1938 r. o powszechnym obowiązku wojskowym, Dz.U. Nr 20, poz. 131 z późn. zm. 
b) duchowni kościołów i związków religijnych, ewangelickich (kościoła ewangelicko-augsburskiego, kościoła ewangelicko-reformowanego, ewangelickiego kościoła augsburskiego i helweckiego wyznania, kościoła ewangelicko-unijnego, staroluterskiego, tudzież innych ewangelickich związków religijnych, uznanych przez państwo polskie), do których zalicza się: wikariuszów, prefektów, diakonów, pastorów, superintendentów, seniorów oraz inne osoby, posiadające charakter osób duchownych w myśl uznanych przez państwo polskie statutów i przepisów kościelnych wymienionych kościołów i związków;

c) duchowni prawosławni, którzy posiadają święcenia, tj. biskupi, prezbiterzy i diakoni; zakonnicy prawosławni, którzy złożyli uroczyste śluby zakonne, tudzież nowicjusze klasztorów prawosławnych;

d) duchowni wyznania mariawickiego uznani przez państwo polskie;

e) duchowni wyznania mojżeszowego, zatwierdzeni (uznani) przez władze państwowe (rabini i podrabini);

f) duchowni muzułmańskiego i karaimskiego związku religijnego uznani przez państwo polskie;

g) duchowni wschodniego kościoła staroobrzędowego, nieposiadającego hierarchii duchownej, uznani przez państwo polskie.

Nie było więc mowy o Świadkach Jehowy. Podobnie rzecz miała się z odroczeniem zasadniczej służby wojskowej (art. 67 ust. 1, lit. b u.p.o.w.), czy zakwalifikowaniem do pomocniczej służby wojskowej (art. 105 ust. 1 u.p.o.w.).

Nowa ustawa o powszechnym obowiązku obrony Polskiej Rzeczypospolitej Ludowej została uchwalona dnia 21 listopada 1967 r. i po licznych nowelizacjach obowiązuje do dnia dzisiejszego ${ }^{18}$. Po nowelizacji dokonanej w 1979 r. ${ }^{19}$ pojawiła się w niej możliwość odbycia zastępczej służby wojskowej, jednakże nie określono motywów, które miały do tego skłaniać poborowych. W art. 117a stwierdzono tylko, że „obowiązkowi odbycia zastępczej służby poborowych podlegają w czasie pokoju uznani za zdolnych do służby wojskowej, którzy nie korzystają z odroczenia zasadniczej służby wojskowej bądź nie

${ }^{18}$ Dz.U. Nr 44, poz. 220 z późn. zm.

${ }^{19}$ Ustawa z dnia 28 czerwca z 1979 r. o zmianie ustawy o powszechnym obowiązku obrony Polskiej Rzeczypospolitej Ludowej, Dz.U. Nr 15, poz. 97. 
mogą odbywać służby wojskowej z przyczyn niezależnych od organów wojskowych, jeżeli zostali przeznaczeni przez wojskowego komendanta uzupełnień do pełnienia tej służby na swoją prośbę". Podobnie motywów odbywania służby zastępczej nie precyzowało rozporządzenie z 1980 r., które w $§ 1$ ust. 1 stanowiło, że ,poborowych przeznaczonych na ich prośbę do zastępczej służby poborowych, powołuje się do odbycia tej służby"20.

Możliwość odbycia zastępczej służby wojskowej inspirowanej przesłankami religijnymi, stała się kategorią normatywną w momencie uchwalenia ustawy o gwarancjach wolności sumienia i wyznania z 17 maja 1989 r. Zgodnie z treścią art. 3 ust. 3, ze względu na przekonania religijne lub wyznawane zasady moralne, obywatele mogli występować o skierowanie ich do służby zastępczej na zasadach i w trybie określonym w ustawie o powszechnym obowiązku obrony Polskiej Rzeczypospolitej Ludowej. Korzystanie z tego prawa wymagało złożenia oświadczenia w sprawie przekonań religijnych lub wyznawanych zasad moralnych. W następnej kolejności w 1992 r. została znowelizowana ustawa z 21 listopada 1967 r. oraz wydano nowe rozporządzenie w sprawie służby zastępczej ${ }^{21}$. Zgodnie z art. 189 ust. 1 ustawy, ,(...) poborowi przeznaczeni do zasadniczej służby wojskowej, zasadniczej służby w obronie cywilnej lub przeszkolenia wojskowego, którzy nie korzystają z odroczenia służby wojskowej, mogą, ze względu na przekonania religijne albo wyznawane zasady moralne, występować do rejonowej komisji poborowej z pisemnymi wnioskami o skierowanie ich do odbycia służby zastępczej”.

Delegacja do uchwalenia ustawy o służbie zastępczej została zawarta w art. 85 ust. 3 Konstytucji RP z 1997 r., który stanowi, że: „obywatel, któremu przekonania religijne lub wyznawane zasady moralne nie pozwalają na odbywanie służby wojskowej, może być obowiązany do służby zastępczej na zasadach określonych w ustawie". Należy zauważyć, że przyznane prawo nie jest prawem bezwzględnym i może zostać

${ }^{20}$ Rozporządzenie Rady Ministrów z dnia 29 września 1980 r. w sprawie zastępczej służby poborowych, Dz.U. Nr 23, poz. 87.

${ }^{21}$ Rozporządzenie Rady Ministrów z dnia 3 listopada 1992 r. w sprawie służby zastępczej, Dz.U. Nr 4, poz. 192. 
ograniczone w sytuacji zaistnienia przesłanek określonych w samej Konstytucji. Zgodnie z art. 31 ust. 3, „ograniczenia w zakresie korzystania $\mathrm{z}$ konstytucyjnych wolności i praw mogą być ustanawiane tylko w ustawie i tylko wtedy, gdy są konieczne w demokratycznym państwie dla jego bezpieczeństwa lub porządku publicznego bądź dla ochrony środowiska, zdrowia i moralności publicznej albo wolności i praw innych osób. Ograniczenia te nie mogą naruszać istoty wolności i praw". Ponadto z tej racji, że klauzula sumienia stricte wiąże się ze sferą wolności sumienia i religii, można te granice wywodzić z art. 53 ust. 5 Konstytucji, który oprócz przesłanki ochrony środowiska zawiera analogiczny katalog 22 .

Ustawa z 28 listopada 2003 r. o służbie zastępczej ${ }^{23}$, określa zasady przeznaczenia do służby zastępczej, kierowania do jej odbycia, a także sposób odbywania służby (art. 1). Warto przyjrzeć się niektórym ze sformułowań użytych przez prawodawcę, budzących pewne wątpliwości interpretacyjne. Otóż w art. 1 określono, że przesłanki, na które może powoływać się osoba wyrażająca wolę odbycia służby zastępczej, wynikać mają z przekonań religijnych lub wyznawanych zasad moralnych. Pojawia się w związku z tym zasadnicze pytanie: czy implikuje to konieczność przynależności do określonego związku wyznaniowego? Możliwe są tutaj różne interpretacje. Wydaje się, że osoba powołująca się na przekonania religijne winna wywodzić je z doktryny określonej religii i pod kątem zgodności z jej doktryną należałoby weryfikować ewentualną motywację. Czy można jednak odmówić powoływania się na przekonania religijne człowiekowi, który nie przynależy do żadnego związku wyznaniowego, a doktrynę religijną tworzy sobie samodzielnie? Wolność sumienia odnosi się do sfery wewnętrznej człowieka, która uwidacznia się na zewnątrz poprzez manifestowanie jej wobec innych ludzi. Przesłankę wyznawanych zasad moralnych można odnosić zarówno do ludzi, którzy wywodzą ją z określonych przekonań religijnych, jak i do osób niewierzących, powołujących się na areli-

${ }^{22}$ Art. 53 ust. 5: „Wolność uzewnętrzniania religii może być ograniczona jedynie w drodze ustawy i tylko wtedy, gdy jest to konieczne do ochrony bezpieczeństwa państwa, porządku publicznego, zdrowia, moralności lub wolności i praw innych osób”.

${ }^{23}$ Dz.U. Nr 223, poz. 2217 z późn. zm. 
gijną motywację, związaną z przynależnością chociażby do subkultury głoszącej poglądy pacyfistyczne.

Ustawodawca nałożył na osobę podlegającą kwalifikacji wojskowej obowiązek udowodnienia prawdziwości przesłanek, które upoważniają do odbycia służby zastępczej. W tym celu należy złożyć stosowny wniosek, zawierający w szczególności oświadczenie o wyznawanych przekonaniach religijnych, jak również wskazanie w wyznawanej doktrynie religijnej podstawy wyłączającej możliwość odbywania służby wojskowej oraz wykazać rzeczywiste związki z wyznawaną doktryną religijną lub wskazać wyznawane zasady moralne, które pozostają W sprzeczności z obowiązkami żołnierza odbywającego służbę wojskową (art. 11 ust. 1 i 2).

Decyzje o przeznaczeniu do służby zastępczej wydaje komisja wojewódzka do spraw służby zastępczej, którą powołuje i odwołuje marszałek województwa, a w jej skład wchodzi 5 osób, w tym przewodniczący i 4 członków (art. 10 ust. 1 i 2). Z kolei od jej decyzji służy odwołanie do komisji do spraw służby zastępczej, powoływanej przez ministra właściwego do spraw pracy, również składającej się z 5 osób, w tym przewodniczącego i członków (art. 13 ust. 1 i 2).W myśl art. 6, do postępowań w sprawach określonych ustawą, stosuje się przepisy kodeksu postępowania administracyjnego, o ile sama ustawa nie stanowi inaczej. Natomiast od wydanych decyzji przysługuje skarga do sądu administracyjnego na zasadach i w trybie określonym w ustawie z dnia 30 sierpnia 2002 r. Prawo o postępowaniu przed sądami administracyjnymi ${ }^{24}$.

Ustawa z dnia 9 stycznia 2009 r. o zmianie ustawy o powszechnym obowiązku obrony Rzeczypospolitej Polskiej oraz o zmianie niektórych innych ustaw ${ }^{25}$, zastąpiła pojęcie ,,poborowy”, określeniem „osoba podlegająca kwalifikacji wojskowej” (art. 13). Z kolei na mocy ustawy z dnia 27 sierpnia 2009 r. o zmianie ustawy o powszechnym obowiązku obrony Rzeczypospolitej Polskiej oraz o zmianie niektórych innych ustaw $^{26}$, zmianie uległ art. 55, który przewidywał obowiązek odbywa-

\footnotetext{
${ }^{24}$ Tekst jedn. Dz.U. z 2016 r., poz. 718 z późn zm.

${ }^{25}$ Dz.U. Nr 22, poz. 120 z późn. zm.

${ }^{26}$ Dz.U. Nr 161, poz. 1278.
} 
nia zasadniczej służby wojskowej przez osoby podlegające kwalifikacji wojskowej. Nowelizacja zawiesiła obowiązek odbywania zasadniczej służby wojskowej, chociaż nie zniosła go całkowicie. W przypadku zagrożenia bezpieczeństwa państwa, jeżeli jest to niezbędne do zapewnienia możliwości wykonywania zadań związanych z przeznaczeniem Sił Zbrojnych, obowiązek służby wojskowej polega także na odbywaniu zasadniczej służby wojskowej przez osoby podlegające temu obowiązkowi. Decyzję w tej materii, na wniosek Rady Ministrów, podejmuje Prezydent RP (art. 55 ust. 2 i 3). Zmieniony art. 32, dotyczy służby wojskowej kobiet i stanowi, że mogą się zgłaszać do kwalifikacji wojskowej, do końca roku kalendarzowego, w którym kończą dwadzieścia cztery lata życia, niezależnie od posiadanych kwalifikacji i wykształcenia, jeżeli ukończyły co najmniej osiemnaście lat życia.

Wraz z zawieszeniem zasadniczej służby wojskowej, zawieszeniu uległa również służba zastępcza. Jednakże obecnie co chwilę pojawiają się doniesienia medialne o powrocie do powszechnego poboru, dlatego też powyższe uwagi na temat obowiązujących regulacji na powrót mogą stać się aktualne.

\subsection{REGULACJE MIĘDZYNARODOWE}

Prawo jednostki do odmowy służby wojskowej ze względu na przekonania nie zostało do tej pory wprost proklamowane i wywodzi się je głównie z norm gwarantujących wolność sumienia i wyznania (wolność religijną) oraz regulacji przewidujących klauzulę sumienia, która również wprost wypływa z wolności religijnej ${ }^{27}$. Jak wskazuje w swoim raporcie Marcin Mróz, zarówno Komisja Praw Człowieka ONZ (KPC ONZ), jak i Parlament Europejski (PE), podejmowały tematykę klauzuli sumienia w służbie wojskowej. KPC ONZ w rezolucjach z 1987 i 1989 r. wezwała do powszechnego uznania prawa do odmowy służby wojskowej ze względów sumienia, apelując jednocześnie do państw o przyjęcie odpowiednich ustaw w tym zakresie. Z kolei

${ }^{27}$ Marek Bielecki, „Wolność religijna”, w: Leksykon prawa wyznaniowego. 100 podstawowych pojęć, red. Artur Mezglewski (Warszawa: Wydawnictwo C.H. Beck, 2014), 513. 
PE w rezolucji z 1989 r. podkreślił, że indywidualne motywacje poborowego powinny wystarczyć do uzyskania odpowiedniego statusu ${ }^{28}$.

Z kolei w 1987 r. Komitet Ministrów sformułował zalecenia dla państw członkowskich Rady Europy, które jego zdaniem winny stanowić punkt odniesienia dla rozwiązań legislacyjnych. W myśl sformułowanej tam zasady podstawowej: , (...) każdy, kto podlega poborowi do służby wojskowej i kto z nieodpartych względów sumienia, odmawia angażowania się $\mathrm{w}$ działania $\mathrm{z}$ użyciem broni, ma prawo być zwolnionym z obowiązku wykonywania takiej służby (...). Osoba taka może być zobowiązana do wykonywania służby zastępczej"29.

Podstawowe dokumenty o zasięgu międzynarodowym, na których opiera się wymiar sprawiedliwości, to Konwencja o ochronie praw człowieka i podstawowych wolności (EKPC) ${ }^{30}$ oraz Karta Praw Podstawowych (KPP) ${ }^{31}$. Kluczowe regulacje zawarte zostały w art. 9 EKPC oraz $\mathrm{w}$ art. $10 \mathrm{KPP}$. Zgodnie $\mathrm{z}$ art. 9 EKPC ust. 1: „Każdy ma prawo do wolności myśli, sumienia i wyznania; prawo to obejmuje wolność zmiany wyznania lub przekonań oraz wolność uzewnętrzniania indywidualnie lub wspólnie z innymi, publicznie lub prywatnie, swego wyznania lub przekonań przez uprawianie kultu, nauczanie, praktykowanie i czynności rytualne". Nowością w stosunku do art. 9 EKPC, i kluczową ze względu na interesujące nas kwestie, jest norma zawarta w art. 10 ust. 2 KPP, w myśl której: „Uznaje się prawo do odmowy działania sprzecznego z własnym sumieniem, zgodnie z ustawami krajowymi regulującymi korzystanie $\mathrm{z}$ tego prawa". W literaturze przedmiotu wskazuje się, że oficjalne tłumaczenie powinno brzmieć:

${ }^{28}$ Mróz, Odmowa stużby wojskowej ze względu na przekonania, 3-4.

${ }^{29}$ Tamże, 4. Autor dokonał tłumaczenia na podstawie: Recommendation No. R(87) of the Committee of Ministers to member states regarding conscientious objection to compulsory military service, w: Conscientious objection to compulsory military service. Recommendation $\mathrm{Nb} \mathrm{R(87)} 8$ adopted by the Committee of Ministers of the Council of Europe on 9 April 1987 and Explanatory report Directorate of Human Rights, Council of Europe Strasbourg 1988.

${ }^{30}$ Konwencja o ochronie praw człowieka i podstawowych wolności z dnia 4 listopada 1950 r., zmieniona protokołami nr 3, 5 i 8 oraz uzupełniona Protokołem nr 2, Dz.U. z 1993 r. Nr 61, poz. 284 z późn. zm.

${ }^{31}$ Karta Praw Podstawowych Unii Europejskiej, DZ.U. UE. C. 2007, nr 303, poz. 1. 
„uznaje się prawo do sprzeciwu sumienia"32. Jednakże nie wpływa to na istotę rzeczonego uprawnienia, zakotwiczonego $\mathrm{w}$ wyznawanych wartościach.

\section{ODMOWA SŁUŻBY WOJSKOWEJ W ŚWIETLE STANOWISKA WYMIARU SPRAWIEDLIWOŚCI}

Nie sposób jest przeanalizować wszystkie sprawy i orzeczenia, które zostały wydane w odniesieniu do Świadków Jehowy, uchylających się od realizacji obowiązku służby wojskowej. Niemniej jednak, proponowany wybór pozwoli zorientować się w ich charakterze oraz prześledzić ewolucję jaka dokonała się na przestrzeni kilkudziesięciu lat. W tym celu analizie zostaną poddane nie tylko orzeczenia, które wprost odnosiły się do Świadków Jehowy, ale również te, które oddziaływały na ich sytuację prawną. Zostaną również zaprezentowane wybrane wyroki Europejskiego Trybunału Praw Człowieka oraz jego poprzedniczki - Komisji Praw Człowieka. Stan faktyczny prezentowanych spraw odtworzony zostanie na podstawie uzasadnień cytowanych orzeczeń.

\subsection{SPRAWY ROZPATRYWANE PRZEZ POLSKI WYMIAR SPRAWIEDLIWOŚCI}

Polski Komitet Wyzwolenia Narodowego (PKWN) postanowił usystematyzować przewinienia jakich dopuszczali się żołnierze bądź kandydaci na żołnierzy w Kodeksie Karnym Wojska Polskiego z dnia 23 września 1944 r. ${ }^{33}$ (KKWP), który uchylał Kodeks Karny Wojskowy z dnia 21 października 1932 r. $^{34}$

${ }^{32}$ Michał Skwarzyński, ,Sprzeciw sumienia w europejskim i krajowym systemie ochrony praw człowieka", Przegląd Sejmowy 6 (2013): 12.

${ }^{33}$ Dekret Polskiego Komitetu Wyzwolenia Narodowego z dnia 23 września 1944 r. Kodeks Karny Wojska Polskiego, Dz.U. Nr 6, poz. 27.

${ }^{34}$ Ustawa z dnia 21 października 1932 r. Kodeks Karny Wojskowy, Dz.U.R.P. Nr 92, poz. 765 . 
Art. $114 \S 1$ KKWP penalizował przestępstwo niezgłoszenia się do odbywania służby wojskowej z zamiarem dłuższego lub trwałego uchylania się od niej, ustanawiając za ten czyn karę do 5 lat pozbawienia wolności ${ }^{35}$. W oparciu o powyższą dyspozycję, wyrokiem Sądu Warszawskiego Okręgu Wojskowego w Warszawie z dnia 17 grudnia 1964 r., Świadek Jehowy został skazany na karę 2 lat i 2 miesięcy więzienia za to, że „mając obowiązek na podstawie karty powołania wystawionej przez WKR do zgłoszenia się w dniu 27 października 1964 r. w jednostce wojskowej celem odbycia zasadniczej służby wojskowej, nie zgłosił się do jej odbywania, mając zamiar trwałego uchylania się, a następnie doprowadzony w dniu 9 listopada 1964 r. do jednostki, odmówił odbywania czynności, wynikających z normalnego toku szkolenia”. Sąd Najwyższy nie dał wiary wnioskowi złożonemu przez obrońcę, starającego się w skardze rewizyjnej, by umorzył postępowanie albo zastosował nadzwyczajne złagodzenie kary ze względu na „fanatyzm religijny”, wynikający z przynależności do Świadków Jehowy ${ }^{36}$.

Na podstawie art. $129 \S 1$ i 2 KKKW, który odnosił się m.in. do sytuacji odmowy wykonania rozkazu wobec żołnierzy, w dniu 22 października 1951 r. Wojskowy Sąd Garnizonowy wydał wyrok skazujący Świadka Jehowy za to, że w trakcie odbywania zasadniczej służby wojskowej, odmówił wykonania rozkazu - przyjęcia broni, a to z uwagi na swoje przekonania religijne ${ }^{37}$.

Uchwalona w 1967 r. ustawa o powszechnym obowiązku obrony Polskiej Rzeczypospolitej Ludowej, przewidywała kary dla osób niezgłaszających się do odbywania służby wojskowej. Zgodnie z art. 231 ust. 3, jeżeli sprawca czynił to w celu trwałego uchylania się od tego obowiązku, podlegał karze pozbawienia wolności od roku do 8 lat. W oparciu o powyższą normę, w dniu 8 lutego 1985 r. Sąd Najwyż-

\footnotetext{
${ }^{35}$ Brzmienie cytowanych przepisów z chwili wydania orzeczenia.

${ }^{36}$ Postanowienie Sądu Najwyższego z dnia 1 lutego 1965 r., Rw 1546/64, OSNKW 1965, nr 7, poz. 87.

${ }^{37}$ Postanowienie Sądu Najwyższego z dnia 11 czerwca 1999 r., WO 8/99 (LEX nr 524084).
} 
szy wydał orzeczenie ${ }^{38}$. Jak wynika z sentencji wyroku, fakt uchylania się od służby wojskowej był wówczas zjawiskiem nagminnym. W tym konkretnym przypadku podjęto decyzję o zaostrzeniu wymiaru kary, co miało stanowić swego rodzaju przestrogę dla osób uchylających się od służby wojskowej. Czyn ten został zakwalifikowany jako społecznie niebezpieczny. Ponadto, zdaniem SN, ,sąd pierwszej instancji zdecydowanie przecenił okoliczności łagodzące, wiążące się z dobrą opinią środowiskową oskarżonego i jego wychowaniem w rodzinie wyznawców grupy religijnej Świadków Jehowy".

Inna sprawa, która doczekała się uchwały SN, dotyczyła Świadka Jehowy, powołującego się na art. 47 ust. 1 ustawy o powszechnym obowiązku obrony Rzeczypospolitej Polskiej, zgodnie z którym poborowych, którzy zostali duchownymi lub członkami zakonów (po profesji wieczystej) przenosi się do rezerwy. Skarżący uznał, że przynależność do zgromadzenia Świadków Jehowy, daje mu prawo do legitymowania się „statusem osoby duchownej”. Sąd Najwyższy stwierdził, że ,za duchownego w rozumieniu tego przepisu nie może być uznany każdy członek Towarzystwa Biblijnego i Traktatowego - Zarejestrowanego Związku Wyznania Świadków Jehowy w Polsce, lecz tylko ten, który wyróżnia się spośród ogółu tym, że powołany został do stałego organizowania i sprawowania kultu religijnego"39.

Po przełomie ustrojowym nastąpiła rewizja większości orzeczeń, jakie zapadały w odniesieniu do Świadków Jehowy w okresie Polski Ludowej. W wyroku z dnia 27 czerwca 2003 r., SN odniósł się do kasacji złożonej przez Prokuratora Generalnego, od wyroku Sądu Wojewódzkiego w Bydgoszczy z dnia 18 marca 1953 r. (sygn. akt IV K $189 / 52)^{40}$. Wśród szeregu zarzutów, jakie postawiono grupie Świadków Jehowy, znalazł się również ten, że niektórzy spośród nich w okresie od maja 1951 r. do maja 1952 r. przechowywali w celu rozpowszechniania i kolportowali czasopismo nawołujące do zbrodni uchylania

${ }^{38}$ Wyrok Sądu Najwyższego z dnia 8 lutego 1985 r., Rw 19/85, OSNKW 1985, nr 9-10, poz. 82.

${ }^{39}$ Uchwała Sądu Najwyższego 7 sędziów z dnia 6 maja 1992 r., I PZP 1/92, OSNKW 1992, nr 7-8, poz. 46.

${ }^{40}$ Wyrok Sądu Najwyższego z 27 czerwca 2003 r., III KK 227/03, OSNwSK 2003, nr 1, poz. 1403. 
się od służby wojskowej, i za to zostali skazani na 3 lata więzienia, czym naruszyli unormowania zawarte w art. $117 \S 1$ i 118 §1 w zw. $\mathrm{z}$ art. $10 \mathrm{KKWP}^{41}$. Sąd Najwyższy zauważył, że „zakwestionowany egzemplarz pisma poruszał wprawdzie dylemat zachowań Świadków Jehowy, co do obowiązującego ich zakazu uczestniczenia w działaniach zbrojnych, ale nie można traktować tych rozważań jako podżegania do popełnienia jakiejkolwiek zbrodni, tym bardziej, iż uchylanie się od służby w wojsku w czasie pokoju stanowiło zwykłe przestępstwo, a nie zbrodnię KKWP, jak orzekł o tym sąd pierwszej instancji”. W sentencji wyroku znalazło się odniesienie do praktyk ówczesnego wymiaru sprawiedliwości, kiedy SN stwierdził, że „odmowa uznania przez władze państwowe wspólnoty religijnej »Świadków Jehowy« jak i innych związków religijnych były sprzeczne z art. 70 Konstytucji PRL z 1952 r. oraz z art. 1 dekretu z dnia 5 sierpnia 1949 r. o ochronie wolności sumienia i wyznania, przyznającym obywatelowi wolność wyznawania każdej religii i prawo swobodnego udziału w wykonywaniu każdego kultu. Dlatego też delegalizacja tego związku nie mogła powodować automatycznym pociąganiem jej członków do odpowiedzialności karnej".

Sprawy Świadków Jehowy rozpatrywane były również przez sądownictwo administracyjne. Wiele $\mathrm{z}$ nich dotyczyło zastępczej służby wojskowej.

Naczelny Sąd Administracyjny w wyroku z dnia 11 maja 1993 r. rozpatrywał sprawę poborowego, który będąc Świadkiem Jehowy nie zgodził się na pełnienie zastępczej służby wojskowej ze względu na przekonania religijne ${ }^{42}$. Został do niej skierowany na mocy orzeczenia Rejonowej Komisji Poborowej z dnia 16 września 1992 r. (nr RKP/

${ }^{41}$ Art. 117 §2: „Kto, będąc obowiązany do służby wojskowej, nie czyni zadość powołaniu lub publicznemu wezwaniu do tej służby w terminie oznaczonym, podlega karze więzienia do lat 2 albo karze aresztu lub skierowaniu do oddziału karnego”. Art. 118 §1: „Kto dopuszcza się przestępstwa, określonego w art. 115, 116, $117 \mathrm{w}$ celu dłuższego lub trwałego uchylenia się od obowiązku wojskowego, podlega karze więzienia do lat 3, a w czasie wojny karze więzienia albo karze śmierci”. Art. 10 §1: „Przestępstwa wojskowe, zagrożone karą śmierci lub karą więzienia powyżej lat 5, są zbrodniami wojskowymi, zagrożone zaś innymi karami zasadniczymi są występkami wojskowymi”.

${ }^{42}$ Wyrok Naczelnego Sądu Administracyjnego we Wrocławiu z dnia 11 maja 1993 r., S.A./Wr 202/93, ONSA 1994, nr 3, poz. 95. 
PR/2/92) i Wojewódzkiej Komisji Poborowej z dnia 5 listopada 1992 r. (nr WKPob. 5213/12/92). Zgodnie z sentencją ogłoszonego wyroku NSA ,(...) obowiązujące prawo nie przewiduje możliwości zwolnienia z powodu przekonań religijnych poborowych, będących wyznawcami Świadków Jehowy od odbycia służby zastępczej”. NSA również negatywnie odniósł się do twierdzeń skarżącego, jakoby służba zastępcza była w jakikolwiek sposób związana z wojskiem. Zdaniem NSA, nie należy traktować tej służby jako formy realizacji służby wojskowej. W świetle art. 4 ust. 2 ustawy o powszechnym obowiązku obrony Rzeczypospolitej Polskiej, jest ona niewątpliwie odrębną postacią wykonania obowiązku obrony ojczyzny. W opinii NSA, ,powołanie się przez poborowego $\mathrm{w}$ jego wniosku na przesłankę "przekonań religijnych « będzie skuteczne tylko w razie wykazania przez wnioskodawcę trwałej przynależności do takiego wyznania, którego reguły nie pozwalają - bez istotnego konfliktu sumienia - na odbywanie służby wojskowej. (...) Wyznawcy różnych kościołów znajdują się w odmiennej sytuacji ze względu na spełnianie przesłanek skierowania do służby zastępczej, wynikających z rygorów doktrynalnych; to zróżnicowanie jednak nie zostało im przyznane, lecz jest rezultatem wyboru (aktu woli). Skoro nauki Kościoła Rzymskokatolickiego nie sprzeciwiają się służbie wojskowej, a kanony wyznania Świadków Jehowy stwarzają nieprzezwyciężone przeszkody takiej służbie, to wyznawcy obu tych kościołów nie znajdują się w takiej samej sytuacji”.

Godne zauważenia i aprobaty jest orzeczenie Wojewódzkiego Sądu Administracyjnego w Warszawie z dnia 14 lipca 2006 r., który rozpatrywał sprawę poborowego, starającego się o odbycie służby zastępczej, motywując to swoimi zasadami moralnymi i etycznymi oraz religijny$\mathrm{mi}^{43}$. Wprawdzie dotyczyło ono katolika obrządku łacińskiego, jednakże można odnieść go do członków innych kościołów i związków wyznaniowych, a także osób niewierzących. NSA zinterpretował wymagania dotyczące wniosku w sprawie służby zastępczej zawarte $\mathrm{w}$ art. 11 ust. 2 ustawy o służbie zastępczej, zgodnie z którymi powinien on zawierać „1) oświadczenie o wyznawanych przekonaniach religijnych;

${ }^{43}$ Wyrok Wojewódzkiego Sądu Administracyjnego w Warszawie z dnia 14 lipca 2006 r., II S.A./Wa 772/06 (LEX nr 258437). 
2) wskazanie w wyznawanej doktrynie religijnej podstawy wyłączającej możliwość odbywania służby wojskowej oraz wykazać rzeczywiste związki z wyznawaną doktryną religijną lub wskazać wyznawane zasady moralne, które pozostają w sprzeczności z obowiązkami żołnierza odbywającego służbę wojskową”. NSA stwierdził, że nie można uzależniać możliwości przeznaczania poborowego do służby zastępczej ,jedynie od wyznawanej religii, ale także od jego zasad moralnych, niepozwalających na pełnienie służby wojskowej”.

NSA zajął się również sprawą żołnierza zawodowego, który złożył wypowiedzenie stosunku służbowego zawodowej służby wojskowej, gdyż, jak stwierdził, po dwóch latach studiowania Pisma Świętego „poznał prawdę o Bogu” i chciał zostać Świadkiem Jehowy, a służba wojskowa w charakterze żołnierza zawodowego stoi temu na przeszkodzie $^{44}$. Jednocześnie wniósł o zwolnienie $\mathrm{z}$ obowiązku pokrywania kosztów zakwaterowania, wyżywienia i umundurowania otrzymanych w czasie nauki w szkole chorążych oraz skrócenia okresu wypowiedzenia i zwolnienia z obowiązków. NSA, utrzymując w mocy decyzję Dyrektora Departamentu Kadr Ministerstwa Obrony Narodowej oraz Ministra Obrony Narodowej, stwierdził, że ,przewidziane w $§ 150$ ust. 1 pkt 1 rozporządzenia Ministra Obrony Narodowej z dnia 28 lipca 1992 r. w sprawie służby wojskowej żołnierzy zawodowych (Dz.U. $\mathrm{Nr}$ 60, poz. 305) zwolnienie żołnierza w służbie stałej od obowiązku zwrotu kosztów »w szczególnie uzasadnionych, nie zawinionych przez żołnierza przypadkach losowych« nie rozciąga się na żołnierzy zawodowych zwolnionych ze służby na ich wniosek z powodu przekonań religijnych".

Sądy Administracyjne rozpatrywały również sprawy osób, które nie będąc Świadkami Jehowy, chciały uchylić się od służby woskowej pod pretekstem popierania ich nauki. W wyroku z dnia 9 października 2006 r. WSA w Warszawie, rozpatrując skargę na orzeczenie Komisji do Spraw Służby Zastępczej, oddalił ją stwierdzając, że „zwolnienie od obowiązku służby wojskowej i skierowanie do służby zastępczej uzasadniać mogą tylko przekonania głęboko utrwalone, należące do

${ }^{44}$ Wyrok Naczelnego Sądu Administracyjnego w Warszawie z dnia 26 stycznia 1994 r., II SA 2328/93, ONSA 1995, nr 2, poz. 60. 
podstawowych wyznaczników postawy poborowego"45. Podobnej sprawy dotyczył wyrok WSA w Warszawie z dnia 25 października 2006 r. ${ }^{46}$ Tutaj poborowy twierdził, że w jego rodzinie są osoby, które należą do Świadków Jehowy, zaś on sam, chociaż nie jest wyznawcą tej religii, to jednak identyfikuje się z nią i w przyszłości zamierza zostać Świadkiem Jehowy.

Oryginalna argumentacja w przedmiocie zwolnienia Świadka Jehowy od służby wojskowej została zastosowana w postanowieniu WSA we Wrocławiu z dnia 28 sierpnia 2008 r. Sąd wstrzymał wykonanie decyzji Szefa Wojewódzkiego Sztabu Wojskowego w przedmiocie powołania do odbycia zasadniczej służby wojskowej ${ }^{47}$. Jako podstawa prawna został przywołany przez sąd art. $61 \S 3$ ustawy z dnia 30 sierpnia 2002 r. Prawo o postępowaniu przed sądami administracyjnymi, zgodnie z którym „sąd może wydać postanowienie o wstrzymaniu w całości lub w części aktu lub czynności, będących przedmiotem zaskarżenia, jeżeli zachodzi niebezpieczeństwo wyrządzenia skarżącemu znacznej szkody lub spowodowania trudnych do odwrócenia skutków”. Sąd nie przywołał okoliczności, które miałyby za tym przemawiać.

\subsection{ORZECZNICTWO EUROPEJSKIEGO TRYBUNAŁU PRAW CZŁOWIEKA}

Analiza dwóch wyroków Europejskiego Trybunału Praw Człowieka (ETPCz), pozwoli zorientować się w linii orzeczniczej prezentowanej zarówno przez Komisję Praw Człowieka, jak i sam Trybunał.

W wyroku z dnia 27 października 2009 r. Europejski Trybunał Praw Człowieka odniósł się do skargi Świadka Jehowy, który został skazany za odmowę służby wojskowej ze względu na swe przekonania ${ }^{48}$.

${ }^{45}$ Wyrok Wojewódzkiego Sądu Administracyjnego w Warszawie z dnia 9 października 2006 r., II SA/Wa 1361/06 (LEX nr 284545).

${ }^{46}$ Wyrok Wojewódzkiego Sądu Administracyjnego w Warszawie z dnia 25 października 2006 r., II SA/Wa 1111/06 (LEX nr 902137).

${ }^{47}$ Postanowienie Wojewódzkiego Sądu Administracyjnego we Wrocławiu z dnia 28 sierpnia 2008 r., IV SA/Wr 394/08 (LEX nr 1077546).

${ }^{48}$ Wyrok Europejskiego Trybunału Praw Człowieka z dnia 27 października 2009 r., w sprawie Bayatyan p. Armenii, skarga nr 23459/03 (LEX nr 523408). 
W skardze została podniesiona okoliczność, iż do chwili jej złożenia ETPCz dość konsekwentnie odmawiał uwzględnienia sprzeciwu sumienia w kwestiach związanych ze służbą wojskową. Jednakże skarżący zwrócił się do ETPCz o rewizję dotychczasowej „konwencyjnej linii orzeczniczej” i potraktowanie Konwencji jako „,̇ywego instrumentu prawnego". Chodziło o to, by Konwencja została zinterpretowana w świetle aktualnych warunków. Odnosząc się do powyższej skargi, ETPCz zinterpretował ją w kontekście art. 4 ust. 3 lit b EKPC, który wyraźnie pozostawił wybór uznania osób odmawiających pełnienia służby wojskowej ze względu na swe przekonania każdemu z Układających się Państw. Dlatego też należało uznać, że ,,art. 9, interpretowany w świetle art. 4 ust. 3 lit. b, nie gwarantuje prawa do odmowy odbycia służby ze względu na przekonania”.

Weryfikacja dotychczasowej linii orzeczniczej ETPC (i jego poprzedniczki Komisji Praw Człowieka) odnośnie odmowy odbycia służby wojskowej, dokonała się w orzeczeniu z dnia 7 lipca 2011 r. $^{49}$ Vahan Bayatyan - Świadek Jehowy - został uznany za zdolnego do służby, ale odmówił jej ze względu na sprzeciw sumienia. Zaznaczył, że jest gotów odbyć alternatywną służbę cywilną. Komisja Parlamentarna ds. Państwowych i Prawnych, do której się odwołał poinformowała go, iż nie ma w Armenii przepisów zezwalających na służbę alternatywną i w styczniu 2003 r. został skazany przez Sąd Kasacyjny za uchylanie się od służby wojskowej na 2,5 roku więzienia. Po kilku miesiącach został warunkowo zwolniony ${ }^{50}$.

ETPC przyznał po raz kolejny, że Konwencja ma być żywym instrumentem prawnym, który musi być interpretowany w świetle warunków dnia dzisiejszego oraz w świetle poglądów dzisiaj dominujących w demokratycznych państwach ${ }^{51}$. Jak podkreślono w orzeczeniu, wąska wykładnia art. 9 dokonywana przez Komisję w świetle art. 4

${ }^{49}$ Wyrok Wielkiej Izby ETPCz z dnia 7 lipca 2011 r. w sprawie Bayatyan p. Armenii, skarga nr 23459/03 (LEX nr 863807).

${ }^{50}$ Omówienie orzeczenia Bayatyan przeciwko Armenii z dnia 7 lipca 2011 r., skarga nr 23459/03, w: Europejski Trybunał Praw Człowieka. Wybór orzeczeń 2011, oprac. Marek Antoni Nowicki (Warszawa: Lex a Wolters Kluwer business, 2012), 360.

${ }^{51}$ Wyrok Wielkiej Izby ETPCz z dnia 7 lipca 2011 r. w sprawie Bayatyan p. Armenii, skarga nr 23459/03 (LEX nr 863807). 
ust. 3, stanowiła odzwierciedlenie poglądów dominujących w czasie jej istnienia. Przywołano orzeczenia Komisji, w których odmówiono uznania sprzeciwu sumienia: Grandrath przeciwko Republice Federalnej Niemiec (decyzja EKPCz z 12 grudnia 1966 r. w sprawie nr 2299/64) oraz X. przeciwko Austrii (decyzja EKPCz z 2 kwietnia 1973 r. w sprawie nr 5591/72). ETPC podkreślił, że do zrewidowania dotychczasowej linii orzeczniczej skłonił go fakt, że pod koniec lat 80. oraz w latach 90. wśród państw europejskich, zarówno ówczesnych państwach członkowskich Rady Europy, jak i w państwach, które przystąpiły do tej organizacji później, zapanowała oczywista tendencja do uznawania prawa do odmowy służby wojskowej ze względu na przekonania. Ponadto Komitet Praw Człowieka Organizacji Narodów Zjednoczonych dokonał wykładni przepisów Międzynarodowego Paktu Praw Obywatelskich i Politycznych (art. 8 i 18), które są podobne do postanowień Konwencji (art. 4 i 9). Pierwotnie Komitet Praw Człowieka ONZ przyjął takie samo podejście jak Europejska Komisja Praw Człowieka, wyłączając prawo do odmowy służby wojskowej ze względu na przekonania spod stosowania art. 18 Paktu. W 1993 r. w swym komentarzu ogólnym nr 22 Komitet uznał jednak, iż ,prawo do odmowy służby wojskowej ze względu na przekonania może zostać wyprowadzone $\mathrm{z}$ art. 18 Paktu w zakresie, w jakim obowiązek stosowania siły mogącej spowodować śmierć, może stać w poważnej sprzeczności z wolnością sumienia oraz prawem do manifestowania swego wyznania lub przekonań”.

\section{PODSUMOWANIE}

Konflikt sumienia z wartościami ogólnoludzkimi, których każdy człowiek winien bronić, takimi jak chociażby bezpieczeństwo ojczyzny, jest kwestią bardzo problematyczną. Trudno jest wskazać „,złoty środek", który pogodziłby poglądy stron bezwzględnie broniących autonomii sumienia oraz stawiających dobro ojczyzny ponad wszystko.

Wydaje się, że rozwiązanie jakie proponuje polski prawodawca w ustawie zasadniczej, nawiązujące do standardów międzynarodowych należy przyjąć z aprobatą. W warunkach pokoju można zapew- 
nić osobom, których poglądy sprzeciwiają się noszeniu broni, służbę zastępczą. Jednakże w sytuacjach zagrożenia bezpieczeństwa ojczyzny prawo to może zostać ograniczone i nie można wykluczyć, że mogą one zostać powołane do służby wojskowej.

Należy zgodzić się z opinią, że klauzula sumienia określana również często jako sprzeciw sumienia, ma chronić jednostkę w sytuacji konfliktu $\mathrm{z}$ nakazami prawa pozytywnego, choć nie powinna prowadzić do tworzenia instrumentu pozwalającego na ignorowanie prawa ${ }^{52}$. Wymiar sprawiedliwości, orzekając w konkretnych sprawach, został niejako „sprowokowany" do oceniania doktryny poszczególnych kościołów i związków wyznaniowych. Orzeczenia wydawane zaś w tego rodzaju sprawach, zdawały się w większości sytuacji pomijać indywidualny wymiar wolności religijnej, gwarantującej każdemu człowiekowi samookreślenie się w sprawach wynikających z jego sumienia.

\section{BIBLIOGRAFIA}

Bednarski, Włodzimierz, Szymon Matusiak. Zmienne nauki Świadków Jehowy. Najważniejsze zmiany $w$ doktrynie Towarzystwa Strażnica $w$ latach 1879-2011. Warszawa: Wydawnictwo Słowo Prawdy, 2012.

Bielecki, Marek. „Wolność religijna”. W: Leksykon prawa wyznaniowego. 100 podstawowych pojęć, red. Artur Mezglewski. Warszawa: Wydawnictwo C.H. Beck, 2014.

Grzebyk, Patrycja. „Idea wojny sprawiedliwej - od starożytności po czasy nowożytne". Forum Prawnicze 2 (2010): 56-73.

Mezglewski, Artur, Henryk Misztal, Piotr Stanisz. Prawo wyznaniowe. Warszawa: Wydawnictwo C.H. Beck, 2006.

Michalak, Ryszard. Polityka wyznaniowa państwa polskiego wobec mniejszości religijnych w latach 1945-1989. Zielona Góra: Oficyna Wydawnicza Uniwersytetu Zielonogórskiego, 2014.

Skwarzyński, Michał. „Sprzeciw sumienia w europejskim i krajowym systemie ochrony praw człowieka". Przeglad Sejmowy 6 (2013): 9-26.

Ufniarski, Stanisław. Międzynarodowe Stowarzyszenie Badaczy Pisma św. (Świadkowie Jehowy). Kraków: Wydawnictwo Mariackie, 1947.

\footnotetext{
${ }^{52}$ Skwarzyński, „Sprzeciw sumienia”, 10.
} 
THE REFUSAL OF MILITARY SERVICE OF JEHOVAH'S WITNESSES

AS AN IMPLEMENTATION OF THE CONSCIENSE CLAUSE

- HISTORICAL AND LEGAL CONDITIONS

\section{Summary}

The subject matter of the present paper is the issue concerning military service of Jehovah's Witnesses. The author mainly focuses on legal regulations and analysis of judicial decisions, nevertheless, the most important aspects of Jehovah's Witnesses teaching are also included. The article presents the evolution of legal regulations as well as the standpoint of jurisdiction in this particular area. The permission to refuse military service of Jehovah's Witnesses had not been granted by either the legislator or the court until the period of system shift. As it is emphasized by the author, problems that arise due to the existing regulations and their practical implementation are believed to become a redundant debate, especially when common military service obligation is suspended. However, in the light of existing threats it cannot be excluded that the military service obligation will be implemented.

Ttumaczenie własne autora

Key words: Jehovah's Witnesses, military service, substitute service, conscientious objection, freedom of conscience and religion, religious freedom

Słowa kluczowe: Świadkowie Jehowy, służba wojskowa, służba zastępcza, sprzeciw sumienia, wolność sumienia i wyznania, wolność religijna 